Keywords: Cholangitis, Döhle bodies, May-Hegglin anomaly

Anahtar Sözcükler: Döhle cisimciği, Kolanjit, May-Hegglin anomalisi

Conflict of Interest: The authors of this paper have no conflicts of interest, including specific financial interests, relationships, and/or affiliations relevant to the subject matter or materials included.

\section{References}

1. Saito H, Kunishima S. Historical hematology: May-Hegglin anomaly. Am J Hematol 2008;83:304-306.

2. Gülen $H$, Erbay $A$, Kazancı E, Vergin C. A rare familial thrombocytopenia: MayHegglin anomaly report of two cases and review of the literature. Turk J Haematol 2006;23:111-114.

\title{
Three Novel Calreticulin Mutations in Two Turkish Patients
}

\author{
İki Türk Hastada Üç Yeni Kalretikulin Mutasyonu
}

\author{
Veysel Sabri Hançer ${ }^{1}$, Hüseyin Tokgöz², Serkan Güvenç ${ }^{3}$ Ümran Çalışkan ${ }^{4}$, Murat Büyükdoğan ${ }^{1}$ \\ ${ }^{1}$ istinye University Faculty of Medicine, Department of Medical Genetics, Istanbul, Turkey \\ ${ }^{2}$ Selçuk University Meram Faculty of Medicine, Department of Pediatric Hematology, Konya, Turkey \\ ${ }^{3}$ Batman District State Hospital, Clinic of Hematology Batman, Turkey \\ ${ }^{4}$ Necmettin Erbakan University Meram Faculty of Medicine, Department of Pediatrics, Konya, Turkey
}

\section{To the Editor,}

Calreticulin (CALR) mutations were first identified exclusively in JAK2-MPL-negative essential thrombocythemia (ET) and primary myelofibrosis (PMF) at a rate of $60 \%-88 \%$, accounting for $1 / 4$ to $1 / 3$ of all patients with ET and PMF $[1,2,3]$. As of today, more than 55 different types of mutations have been reported. The two most common mutations accounting for $85 \%$ of mutated cases are either a 52-bp deletion (type 1 ; c. 1099_1150del; L367fs*46; 44\%$53 \%$ of cases) or a 5 -bp insertion (type 2; c.1154_1155insTTGTC; K385fs* $47 ; 32 \%-42 \%$ of cases). The remaining 15\% include various other infrequent mutations that are often unique or found in only a few patients $[4,5]$.

Here we present three CALR mutations in two patients with PMF and $E T$ that have not been reported before as shown in Figure 1. Known CALR mutations and BCR-ABL, JAK-2 V617F, and MPL $515 \mathrm{~L} / \mathrm{K}$ test results were found to be negative.

Patient 1: The patient was a 46-year-old man with low back pain. Magnetic resonance imaging scanning of the lumbosacral region revealed sacroiliitis on the left side and he was referred to a rheumatologist for further investigations. Anemia ( $\mathrm{Hb}$ : $10.8 \mathrm{~g} / \mathrm{dL})$ and thrombocytosis $\left(700 \times 10^{9} / \mathrm{L}\right)$ with a high lactate dehydrogenase level $(351 \mathrm{U} / \mathrm{L})$ were found in initial tests. The other tests for a possible rheumatologic disease, including

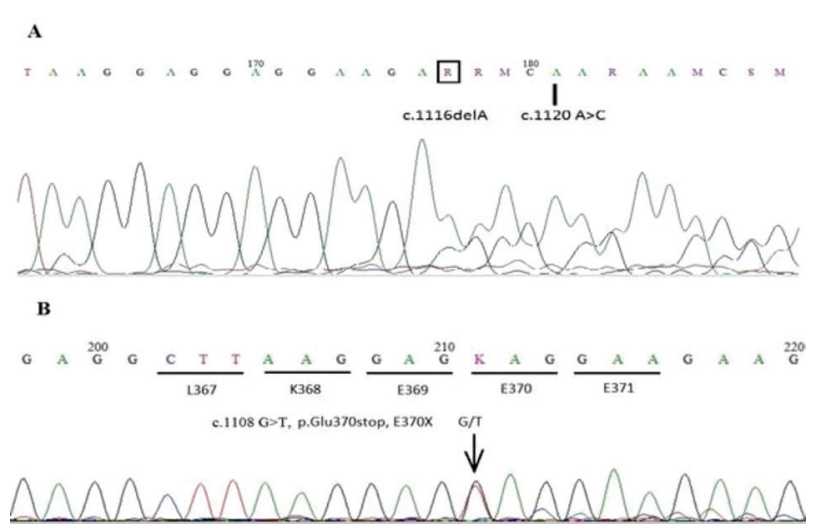

Figure 1. A) Electropherogram result of the primary myelofibrosis patient, B) electropherogram result of the essential thrombocythemia patient.

human leukocyte antigen-B27, were all negative when the patient was seen. Physical examination was almost normal with no sign of organomegaly. Spleen size was also normal in the abdominal ultrasound. The peripheral blood smear showed dacrocytes, occasional myelocytes (1\%), and metamyelocytes (1\%). The bone marrow biopsy showed diffuse grade 3-4 reticulin fibrosis with atypical proliferation of megakaryocytes and increased cellularity consistent with PMF.

Patient 2: A 9-year-old pediatric patient with thrombocytosis $\left(2800 \times 10^{9} / \mathrm{L}\right)$ was identified in a routine check-up. Physical 
examination was normal except for mild splenomegaly. Complete blood count revealed increased platelet count $\left(2800 \times 10^{9} / \mathrm{L}\right)$ with normal hemoglobin and leukocyte count. Platelets were very abundant and clustered in the peripheral blood smear. Bone marrow aspiration and biopsy examinations showed tri-lineage hematopoiesis with an increased number and clusters of megakaryocytes without fibrosis, which is consistent with ET. She had persistently elevated platelet counts ranging between $2000 \times 10^{9} / \mathrm{L}$ and $2800 \times 10^{9} / \mathrm{L}$ without any evidence of reactive/secondary thrombocytosis such as infections, medicine, autoimmune disorders, neoplasms, trauma, surgery, or hematological disorders such as iron deficient anemia, chronic hemolytic situations, and acute hemorrhages.

Genomic DNA was extracted from whole blood, exon 9 of the CALR gene was amplified by polymerase chain reaction, and then the amplified fragments were sequenced. All nucleotide numbers refer to the wild-type cDNA sequence of CALR (NM_004343) as reported in Ensembl. Here we report three new $C A L R$ mutations [1-bp deletion; c.1116delA (D373fs*57) and c.1120 A>C] in the same patient with PMF and c.1108 G>T in a patient with ET. We performed germline testing from the cheek epithelium and both patient samples were confirmed as wild-type CALR. These novel mutations occurred and changed the amino acid sequence of the $\mathrm{C}$ domain amino acid residues, which will interfere with the calcium-binding capacity of the molecule. It is important to determine the type of mutation. Type 2-like CALR mutations are mainly associated with an ET phenotype, low risk of thrombosis, and indolent clinical course, while type 1-like mutations are mainly associated with a myelofibrosis phenotype and a high risk of progression from ET to myelofibrosis. The identification of new CALR mutations will improve our understanding of the pathophysiology of myeloproliferative neoplasms.

Keywords: Essential thrombocythemia, Primary myelofibrosis, Calreticulin

Anahtar Sözcükler: Esansiyel trombositemi, Primer miyelofibroz, Kalretikulin

Conflict of Interest: The authors of this paper have no conflicts of interest, including specific financial interests, relationships, and/or affiliations relevant to the subject matter or materials included.

\section{References}

1. Klampfl $T$, Gisslinger $H$, Harutyunyan AS, Nivarthi $H$, Rumie $E$, Milosevic JD, Them NC, Berg T, Gisslinger B, Pietra D, Chen D, Vladimer Gl, Bagienski K, Milanesi C, Casetti IC, Sant'Antonio E, Ferretti V, Elena C, Schischlik F, Cleary C, Six M, Schalling M, Schönegger A, Bock C, Malcovati L, Pascutto C, Superti-Furga G, Cazzola M, Kralovics R. Somatic mutations of calreticulin in myeloproliferative neoplasms. N Engl J Med 2013;369:2379-2390.

2. Fu R, Zhang L, Yang R. Paediatric essential thrombocythaemia: clinical and molecular features, diagnosis and treatment. Br J Haematol 2013;163:295302.

3. Guglielmelli $P$, Nangalia J, Green AR, Vanucchi A.M. CALR mutations in myeloproliferative neoplasms: hidden behind the reticulum. Am J Hematol 2014;89:453-456.

4. Tefferi $A$, Wassie EA, Guglielmelli $P$, Nangat $N$, Belachew AA, Lasho TL, Finke C, Ketterling RP, Hanson CA, Pardanani A, Wolanskyj AP, Maffioli M, Casalone R, Pacilli A, Vannucchi AM, Passamonti F. Type 1 versus Type 2 calreticulin mutations in essential thrombocythemia: a collaborative study of 1027 patients. Am J Hematol 2014;89:121-124.

5. Giona F, Teofili L, Capodimonti S, Laurino M, Martini M, Marzella D, Palumbo G, Diverio D, Foà R, Larocca LM. CALR mutations in patients with essential thrombocythemia diagnosed in childhood and adolescence. Blood 2014;12:3677-3679.
Address for Correspondence/Yazışma Adresi: Veysel Sabri HANÇER, M.D. İstinye University Faculty of Medicine, Department of Medical Genetics, İstanbul, Turkey Phone : +905336343014

E-mail : vshancer@yahoo.com ORCID-ID: orcid.org/0000-0003-2994-1077
Received/Geliş tarihi: April 05, 2017 Accepted/Kabul tarihi: July 26, 2017

DOI: $10.4274 /$ tjh.2017.0146 